\title{
ANALYSIS OF THE INFLUENCE OF MULTINATIONAL, AUDIT QUALITY AND COMPANY SIZE ON THIN CAPITALIZATION OF MANUFACTURING COMPANIES LISTED ON THE IDX
}

\author{
Vonny Whidyawhati, Dian Purnama Sari \\ Universitas Katolik Widya Mandala Surabaya
}

\begin{abstract}
Tax avoidance can be carried out through some schemes, one of them is through thin capitalization. Thin capitalization is a tax avoidance practice carried out by companies through financing their business from high debt instead of capital. In Indonesia, thin capitalization is first regulated in KMK-1002/KMK.04/1984 which later changed to PMK 169/ PMK.010/2015. The purpose of this study is to analyze the effect of multinational, quality audits, and company size on thin capitalization. The research object includes manufacturing companies listed on IDX within the period of 2017-2019. The sample obtained includes 299 companies. This study uses secondary data in the form of financial reports. The data analysis technique used in this study is multiple regression analysis. The results show that multinational have no effect on thin capitalization, audit quality has negative effect on thin capitalization and firm size has positive effect on thin capitalization.
\end{abstract}

Keywords: thin capitalization, multinational, audit quality, firm size

\section{INTRODUCTION}

Indonesia's largest source of income comes from taxes. As of December 31, 2019, taxes contributed IDR 1,332.06 trillion to the state, while customs and excise contributed IDR 213.27 trillion, and Non-Tax State Revenues (NTSR) contributed IDR 405.04 trillion (Ministry of Finance, 2020). However, even though tax has managed to raise a huge funds for the government, these amounts of funds can be more optimal. This is shown by the absence of realized tax

\footnotetext{
*Corresponding Author.

e-mail: vonnyy21@gmail.com
} 
revenue in 2019. The target was set at IDR 1,577.56 trillion, however only IDR 1332.06 trillion was realized. Based on the number of Annual Income Tax Returns of 1770 and 1771 reported in 2019, out of a total of 4,514,765 taxpayers, 1,257,198 did not report their annual tax return. Few reasons that cause this condition are the lack of supervision to the taxpayers as well as the limited education regarding taxpayer supervision. (Directorate General of Taxes, 2019). One of the reasons why the realization of tax revenue is low is caused by taxpayers who avoid their obligations to pay taxes. Yulyanah \& Kusumastuti (2019) stated that Indonesia suffered a loss of US $\$ 6.48$ billion due to tax evasion done by companies.

Thin capitalization is a form of tax avoidance practices carried out by companies by funding their business through high debt instead of capital. One of the factors that influence companies in making capital structure decisions is tax (Brigham \& Houston, 2019). If the company chooses to finance its business from capital money, the company must distribute their dividends, where the dividends will be taxed. So, if the company chooses to finance from the capital, the same tax object will be taxed twice. First, for calculating the company's income tax expense, and second is when the dividend is distributed. Meanwhile, if the company chooses to finance their business from debt, the consequence is interest expense. Dividend is non-deductible, while interest is deductible, which means that the interest expense can be used as a deduction for profit. This brings problems to the tax authorities because many companies choose to finance their operation via high debt as a form of tax avoidance. According to the agency theory, this is due to the different interests between the agent and principal. The agent is the taxpayer, while the principal is the tax authority. For tax authorities, tax is a source of income that can increase the state revenue. While from the taxpayer's point of view, tax is an expense that does not give any added value and instead reduces profit. The difference of interest is reflected in the attitude of the agent who tries to maximize profits by reducing the expenses, including tax expense while the principal tries to get the highest state revenue to finance the state's operations. In general, thin capitalization has two approaches: (1) determining the maximum amount of debt for deductible interest payments and (2) determining the maximum limit of deductible interest by referring to the interest ratio (OECD, 2012). This regulation was made to stop profit shifting 
through excessive corporate debt, so that it can protect a country's tax revenue. In Indonesia, thin capitalization was first regulated in KMK-1002/KMK.04/1984. This regulation states that the highest ratio of debt to equity allowed is $3: 1$ (Article 1). However, the Keputusan Menteri Keuangan (KMK) seems to have been made hastily because it does not regulate some basic matters, such as taxpayers stipulated in the regulation, or define the meaning of interest. Finally, in 2015 the Government issued PMK 169/PMK.010/2015. This regulation states that the highest ratio of debt to equity allowed is 4:1 (Article 2 (1)).

Multinational companies are often suspected to implement tax avoidance. Purba \& Tran (2018) stated that multinational companies are proven to divert profits from Indonesia. Multinational companies have a higher chance of avoiding taxes compare to domestic companies because multinational companies often have branches in different countries, which have different tax rates and different tax rules that can be utilized by the companies. Indonesia's tax ratio is $11.9 \%$, which is the lowest compared to other ASEAN countries (OECD, 2020). Multinational companies tend to conduct thin capitalization by carrying out interest-bearing debt between the parent company and the branches or subsidiaries in other countries by exploiting the different taxation rules between countries. This is supported by Nugroho \& Suryarini (2018) and Waluyo \& Doktrolalina (2018) who stated that multinationals significantly affect thin capitalization.

The existence of an audit process makes the company more likely to be transparent in reporting its financial statements, including their tax expense. The quality of the auditor is the main characteristic that is considered in selecting auditors. Thus, this factor is believed to affect tax avoidance (Khairunisa et al., 2017). Audit quality is the extent to which auditors can report information appropriately in accordance with the standards (Yadiati \& Mubarok, 2017). If a company's debt to equity ratio exceeds the predetermined limit, this can indicate that the company is practicing thin capitalization. A qualified auditor will be able to detect this. Khairunisa et al. (2017) stated that tax avoidance is influenced by audit quality.

Larger companies will have more complex activities and transactions. Large companies have a greater opportunity to practice thin capitalization by carrying out interest-bearing debt between the parent company and the branches or subsidiaries. In Indonesia, the interests rate in 2017 was 4.56\%, in 2018 was 
5.06\%, and in 2019 was 5.63\% (Bank Indonesia, 2020). Compared with the corporate income tax rate of $25 \%$ (down to $22 \%$ in April 2020), the interest rate is low. This causes companies to prefer to do interest-bearing debt with its affiliates because the company can reduce the tax expense paid by making interest-bearing debt. Nugroho \& Suryarini (2018) stated that company size affects thin capitalization significantly.

Currently, existing research are more focused on tax avoidance as a whole concept, rather than focusing on thin capitalization itself. The object of this research includes companies which are classified within the manufacturing sector because in the raw material income sector there is a mining sub-sector, while in the service sector there are infrastructure, utilization and transportation and finance sub-sectors where all three are taxpayers are exempted from PMK 169/ PMK.010/2015.

\section{The Effect of Multinational on Thin Capitalization}

Multinational companies are companies that do not operate only in one country, but also in other countries. These companies earn profits from various countries. They tend to perform high interest debt with the subsidiaries or branches located in other countries and exploit tax regulations in the countries. Multinational companies often use thin captilazation schemes as a tax avoidance (Putranti et al., 2015). Nugroho \& Suryarini (2018) and Waluyo \& Doktrolalina (2018) stated that thin capitalization is significantly influenced by multinationals. Thus, the first hypothesis proposed is:

H1: Multinational has a positive effect on thin capitalization.

\section{The Effect of Audit Quality on Thin Capitalization}

Audit quality is the extent to which auditors can report information appropriately in accordance with the standards (Yadiati \& Mubarok, 2017). Audit is an effort to minimize the difference of interest between the agents and the principals. Through audits, it is hoped that companies can be more transparent in reporting their financial reports, including their tax expenses. Companies must be careful in planning their tax. If the company does tax avoidance, which can be done through a thin capitalization scheme, the company must bear the 
risk of the auditor finding out about it. In addition, audit process is expected to minimize tax avoidance by the company. Khairunisa et al. (2017) stated that the quality of an auditor affects tax avoidance. Thus, the second hypothesis proposed is:

H2: Audit quality has a negative effect on thin capitalization.

\section{The Effect of Company Size on Thin Capitalization}

Company size describes the scale of a company. Total assets can be used as a measurement to classify company size. Large companies will have larger total assets as well. Companies with high total assets can be considered to have the ability to generate more stable and higher profits compare to companies with lower total assets. The higher the profit the company gets, the higher the tax expense that must be paid. This could trigger tax avoidance. Suntari \& Mulyani (2020) stated that large companies have high DER ratios, thus the probability of large companies to practice thin capitalization is higher. Nugroho \& Suryarini's (2018) research stated that company size affects thin capitalization. Thus, the third hypothesis proposed is:

H3: Firm size has a positive effect on thin capitalization.

\section{METHOD}

\section{Research Design}

This research is a quantitative research. This research was conducted to determine the effect of multinational, audit quality and company size towards thin capitalization. This study uses secondary data obtained from the annual reports of manufacturing companies listed on the Indonesia Stock Exchange during the period 2017-2019.

\section{Research Variables}

The dependent variable is thin capitalization, a tax avoidance scheme used by companies where companies take advantage of high debt in their funding. Thin capitalization can be measured through the Debt-to-Equity Ratio (DER). 
DER is used as the measurement because PMK 169/PMK.010/2015 states that the maximum allowable ratio between debt and capital is $4: 1$. DER is a ratio that shows the comparison of the composition of a company's capital structure. This ratio shows the difference between capital originating from debt and from investors. The higher the ratio is, the higher the funding that comes from debt will be (Utami \& Hidayah, 2017).

$$
\text { Debt to Equity Ratio (DER) }=\frac{\text { Total Liability }}{\text { Total Equity }}
$$

Multinational will be measured using dummy variables. If the company has at least 5 branches or subsidiaries outside Indonesia, it will be given a value of 1. If the company has less than 5 branches or subsidiaries outside Indonesia, it will be given a value of 0 (Nugroho \& Suryarini, 2018).

Audit quality will be measured using dummy variables (Choiriyah \& Mulyani, 2019). If the company uses the Big Four Accounting Firms as its auditor, the company will be given a value of 1 . If the company uses a non-Big Four Accounting Firms as its auditor, the company will be given a value of 0 . Big Four Accounting Firms here includes Ernst \& Young (EY), PricewaterhouseCoopers (PwC), Klynveld, Peat, Marwick, Goerdeler (KPMG), and Deloitte Touche Tohmatsu (Deloitte).

Company size can be measured using the natural logarithm of sales or total assets. For this study, it is using natural logarithmic of total assets as the measurement (Pratama, 2017) and (Nugroho \& Suryarini, 2018). This measurements is used because asset values tend to be more stable than sales (Purba \& Kholis, 2017).

$$
\text { Company size }=\text { Ln (Total Assets) }
$$

\section{Analysis Method}

The data analysis technique used in this study is multiple regression analysis (Duli, 2019) and (Ghozali, 2018). Data processing will be assisted by the Statistical Package for Social Science (SPSS) program. The relationship between hypotheses is shown through the equation below:

$$
\text { THINCAP }=\alpha+\beta 1 \text { MULTI }+\beta 2 \text { QUALITY }+\beta 3 \text { SIZE }+\varepsilon
$$


Explanation:

$$
\begin{array}{ll}
\text { THINCAP } & =\text { Thin Capitalization } \\
\alpha & =\text { Constant } \\
\beta 1,2,3 & =\text { Regression Coefficient } \\
\text { MULTI } & =\text { Multinational } \\
\text { QUALITY } & =\text { Audit Quality } \\
\text { SIZE } & =\text { Ukuran Perusahaan } \\
\varepsilon & =\text { Company Size }
\end{array}
$$

\section{RESULTS}

The population of this study includes manufacturing companies listed in Indonesia Stock Exchange in the period of 2017-2019. This study uses a purposive sampling method with the following criteria:

Table 1 Sample Criteria

\begin{tabular}{ccc}
\hline No. & Description & Total \\
\hline 1. & $\begin{array}{l}\text { Manufacturing companies listed on the Indonesia Stock Exchange } \\
\text { that published complete financial reports during the 2017-2019 }\end{array}$ & 444 \\
$\begin{array}{l}\text { period. } \\
\text { 2. Companies that do not use the rupiah currency (Rp) in their financial }\end{array}$ & $(99)$ \\
$\begin{array}{l}\text { statements } \\
\text { 3. Companies that incur losses during the study period }\end{array}$ & $(36)$ \\
Total companies & 309 \\
Total companies deducted when outliers & $(10)$ \\
Total research sample & 299 \\
\hline
\end{tabular}

\section{Descriptions of the Research Variables}

The results of the descriptive statistics can be seen in Table 2 below:

Table 2 Descriptive Statistics

\begin{tabular}{lrrrrr}
\hline & N & Minimum & Maximum & Mean & $\begin{array}{c}\text { Std. } \\
\text { Deviation }\end{array}$ \\
\hline THINCAP & 299 & .06966 & 2.9407 & .81733 & .62766 \\
SIZE & 299 & 25.48905 & 33.66952 & 28.54809 & 1.61046 \\
Valid N (listwise) & 299 & & & & \\
\hline
\end{tabular}


Based on the results of the data processing, in 2019, PT Indal Aluminum Industry Tbk is the company with the highest thin capitalization (THINCAP) value, which is 2,9407 . This means that the manufacturing company listed on IDX do not exceed the regulatory limits set out in PMK 169, which stated that the maximum allowable ratio of debt to capital is 4: 1. PT Inti Agri Resources Tbk is the company with the lowest thin capitalization value of 0.06966 . The mean value of thin capitalization is 0.81733 . This means that on average, the manufacturing companies listed on the IDX prefer to fund their companies using capital and not debt. The standard deviation value is 0.62766. PT Asiaplast Industries Tbk has the highest SIZE value of 33.66952, while PT Prima Cakrawala Abadi Tbk is the company with the lowest SIZE value of 25.48905. The mean of SIZE is 28.54809 with a standard deviation of 1.61046 .

Table 3 Descriptive Statistics of Multinational Variable

\begin{tabular}{lcc}
\hline \multicolumn{1}{c}{ Information } & Frequency & Percentage \\
\hline Has multinational characteristics & 24 & $8 \%$ \\
Does not have multinational characteristics & 275 & $92 \%$ \\
Total & 299 & $100 \%$ \\
\hline
\end{tabular}

The MULTI variable is measured using a dummy variable, where the percentage of the MULTI variable can be seen in Table 3. There are 24 out of 299 companies that have multinational characteristics, while the rest (275 out of 299 companies) that do not have multinational characteristics.

Tabel 4 Descriptive Statistics of Quality Variable

\begin{tabular}{lcc}
\hline \multicolumn{1}{c}{ Information } & Frequency & Percentage \\
\hline Audited by Big Four Accounting Firms & 102 & $34 \%$ \\
Audited by Non-Big Four Accounting Firms & 197 & $66 \%$ \\
Total & 299 & $100 \%$ \\
\hline
\end{tabular}

The QUALITY variable is measured using a dummy variable, where the percentage of the variable is presented in Table 4 . The total companies audited 
by the Big Four Accounting Firms are 102 out of 299, while the total companies that were not audited by the Big Four Accounting Firms are 197 out of 299.

\section{DISCUSSION}

Based on the test results of the multiple linear regression analysis, the following results are obtained:

Table 5 Multiple Linear Regression

\begin{tabular}{llrrrrr}
\hline \multicolumn{7}{c}{ Coefficients $^{\mathrm{a}}$} \\
\hline \multirow{2}{*}{ Model } & & \multicolumn{2}{c}{$\begin{array}{l}\text { Unstandardized } \\
\text { Coefficients }\end{array}$} & $\begin{array}{c}\text { Standardized } \\
\text { Coefficients }\end{array}$ & \multirow{2}{*}{$\mathbf{t}$} & \multirow{2}{*}{ Sig. } \\
\cline { 3 - 5 } & & B & $\begin{array}{c}\text { Std. } \\
\text { Error }\end{array}$ & Beta & & \\
\hline \multirow{2}{*}{1} & (Constant) & -3.080 & .424 & & -7.256 & .000 \\
& MULTI & -.125 & .078 & -.093 & -1.612 & .108 \\
& QUALITY & -.206 & .049 & -.266 & -4.176 & .000 \\
& SIZE & .103 & .015 & .449 & 6.760 & .000
\end{tabular}

a. Dependent Variable: Log_THINCAP

Based on Table 5, the below equation is obtained:

THINCAP $=-3,080-0,125$ MULTI $-0,206$ QUALITY $+0,103$ SIZE $+\varepsilon$

\section{The Effect of Multinational on Thin Capitalization}

Through this research, it was found that Hypothesis 1 was rejected. Based on the results of the hypothesis testing, multinational companies has no effect on thin capitalization. This means that this finding is in line with Himmah's (2020) findings which stated that multinational have no influence on thin capitalization. This finding also indicates that companies with multinational characteristics tend to not avoid taxes through thin capitalization. In addition, the results of this study break the assumption that multinational companies tend to undertake thin capitalization schemes by making high-interest debt with subsidiaries or branches in other countries and exploiting tax regulations in different countries. Compa- 
nies decided to expand their branches or subsidiaries in other countries purely to expand its busines, and to fulfil other factors, such as the availability of resources, cheap labor, etc., and not solely for tax avoidance purposes. Furthermore, the number of manufacturing companies listed on the IDX that show multinational characteristics are decreasing. The percentage of manufacturing companies with multinational characteristics is about $8 \%$. This may occur because Indonesia imposes attractive tax incentives for foreign investors, so they do not need to do tax avoidance to reduce their tax expense. The policies include tax holidays and tax allowances. Tax holiday is a facility provided companies to engage in certain industries where the company will be exempted from corporate income tax for a minimum of 5 years to a maximum of 20 years in accordance with the provisions stipulated in PMK 35 of 2018. While tax allowance is a facility given to certain field of businesses as regulated in PP no. 78 of 2019, where the facilities provided receive a reduction in net income by $30 \%$ of the total investment or compensation for losses that are longer than 5 years, but not more than 10 years.

\section{The Effect of Audit Quality on Thin Capitalization}

Based on the hypothesis testing, the results show that audit quality negatively affects thin capitalization. This means that this study is in line with Khairunisa et al. (2017) who stated that audit quality negatively affects tax avoidance. Auditors are independent parties who have different interests from taxpayers. The auditor has no interest in evading taxes or helping their clients to avoid taxes. The presence of auditors is expected to reduce or even prevent tax evasion. This study proves that good auditors can detect fraud better and can produce more transparent financial reports. Thus, actions such as thin capitalization are reduced. Through audits, companies become more transparent in reporting their finances, including tax expenses. If the company does tax avoidance, which can be done through a thin capitalization scheme, the company must also bear the risk of auditors finding out about it. This study shows that the audits conducted by the Big Four have proven to be in good quality, so that they reduce thin capitalization as one of the company's tax avoidance schemes. Tax avoidance has a negative connotation, so the auditors do not want their clients 
to do tax avoidance, especially as Big Four Accounting Firms auditors have a reputation that must be maintained. If the company continues to do thin capitalization with the acknowledgment from the auditors, then the auditor can give their opinion other than unqualified opinion. If this happens, the shareholders may lose interest in investing their money in the company because it proves that the company does not have good management where the company's financial statements receive an opinion other than unqualified opinion.

Big Four Accounting Firms are also believed to be competent and independent, so that the auditors from the Big Four Accounting Firms have better knowledge and abilities in detecting fraud and manipulation of financial reports by the company. The Big Four Accounting Firms will not allow its clients to undertake thin capitalization because if this is known by the Director General of Taxes, the Big Four Accounting Firms is at risk of being viewed as bad, and the public's does not trust the Accounting Firms as much. Qualified auditors will also be more careful in carrying out their duties, especially in examining the financial statements of companies listed on the IDX because they are supervised by an authorized body, such as the Financial Services Authority (Otoritas Jasa Keuangan). The better the quality of the auditor is, the more transparent the company's financial statements will be. Auditors who present good quality will avoid lawsuits and fraud (Khairunisa et al., 2017). Thus, it can be concluded that Hypothesis 2, which states audit quality has a negative effect on thin capitalization, is proven.

\section{The Effect of Company Size on Thin Capitalization}

Based on the hypothesis testing, the results show that company size positively affects thin capitalization. This research is in line with Nugroho \& Suryarini (2018) which stated that company size affects thin capitalization. This indicates that the bigger a company is, the higher their tax avoidance activities will be carried out through thin capitalization. Bigger companies will have higher profit, which also means that their tax expense is higher. It is more likely for these companies to avoid taxes, so that the profits obtained by the company can be maximized (Nugroho \& Suryarini, 2018). Larger companies have greater opportunities to undertake thin capitalization by carrying out interest-bearing 
debt between the parent company and the branches or subsidiaries. This is in line with the agency theory which states that there are differences of interests between agents (taxpayers) and principals (tax authorities). The difference of interests is because the taxpayer wants to get the highest profit, while the Tax Authority tries to get the highest state revenue to finance the state operations. This difference in interests leads to tax avoidance practices. This study proves that the greater the company size is, the higher the possibility for the company to conduct thin capitalization. This is indicated by the high DER ratio of large companies (Nugroho \& Suryarini, 2018). This also shows that large companies preference lean on financing their business through interest-bearing debt rather than capital and take advantage of differences in tax treatment between interest expenses and dividends. So, it can be concluded that Hypothesis 3, which states company size has a positive effect on thin capitalization is proven, is accepted.

Based on the research that has been done, the following implications can be stated:

1. Multinational has no effect on thin capitalization. This may be cause by companies' decision to establish a branch or subsidiary outside Indonesia solely for the purpose of expanding its business, not for tax avoidance. Indonesia provides many incentives in the field of taxation, so foreign investment (PMA) does not need to carry out thin capitalization to reduce its tax expense. In other hand, the number of manufacturing companies listed on the IDX with multinational characteristics are decreasing. The percentage of manufacturing companies that have multinational characteristics is only about $8 \%$.

2. Audit quality has a negative effect on thin capitalization. This indicates that good auditors can detect fraud better and can create more transparent financial reports. Thus, actions, such as thin capitalization, are reduced. Qualified auditors will also be more careful in carrying out their duties, especially in examining financial statements of the companies listed on IDX because they are supervised by an authorized body, such as the Financial Services Authority (Otoritas Jasa Keuangan).

3. Company size has a positive effect on thin capitalization. The bigger the company size is, the greater the profit will be. This causes a greater tax expense that must be paid by the company and this also causes large 
companies to have a bigger tendency to show thin capitalization. Larger companies tend to choose to finance their business through interest-bearing debt rather than capital and take advantage of the difference in tax treatment between interest expense and dividends.

\section{Conclusions, Limitations, and Suggestions}

Based on the analysis that have been done in this research, the results show that multinationals have no effect on thin capitalization, while audit quality has a negative effect on thin capitalization, and company size has a positive effect on thin capitalization. The study's limitations include first, heteroscedasticity occurred in this study, wherein the heteroscedasticity test indicate that the significance was 0.033 . Data normalization, data outliers, and residual values are absolute, but the regression results show that the significance value is below 0.05 . Second, the number of manufacturing companies with multinational characteristics included in this research are very limited, with only 24 companies out of 299 companies obtained as the sample group of this study.

The suggestions that can be given is further research is expected to expand the independent variable using other variables, such as Good Corporate Governance, Profit Growth, Business Strategy, and others. A practical advice for the Directorate General of Taxes is that this research is expected to be used as a consideration to evaluate the existing thin capitalization regulations in Indonesia. The Directorate General of Taxes can further tighten oversight of large companies because they are proven to still practicing thin capitalization. The Directorate General of Taxes is also expected to immediately create thin capitalization regulations for taxpayers who are exempted from PMK 169 / PMK 010/2015.

\section{REFERENCES}

Brigham, E. F. \& Houston, J. F. (2019). Fundamentals of Financial Management (edisi ke-15). Boston: Cencage Learning Inc.

Bank Indonesia. (2020). BI 7-day (Reverse) Repo Rate. Didapatkan dari https:// www.bi.go.id/id/moneter/bi-7day-RR/data/Contents/Default.aspx. 
Choiriyah, Y. \& Mulyani, S. D. (2019). Pengaruh Thin Capitalization dan Profitability terhadap Tax Avoidance dengan Audit Quality sebagai Variabel Moderating. Forum Keuangan Dan Bisnis (FKBI), 7, 161-168.

Direktorat Jenderal Pajak (2019). Laporan Kinerja Direktorat Jenderal Pajak (2019). Didapatkan dari https://www.pajak.go.id/sites/default/files/2020-02/ LAKIN\%20DJP\%202019.pdf.

Duli, N. (2019). Metodologi Penelitian Kuantitatif: Beberapa Konsep Dasar untuk Penulisan Skripsi \& Analisis Data dengan SPSS. Yogyakarta: Deepublish Publisher.

Ghozali, I. (2018). Aplikasi Analisis Multivariate dengan Program IBM SPSS 25 (edisi ke-9). Semarang: Badan Penerbit Universitas Diponegoro.

Himmah, F. F. (2020). Analysis of Tax Elimination with Thin Capitalization. Jurnal Akuntansi, Audit dan Sistem Informasi Akuntansi, 4(2), 166-182.

Kementrian Keuangan. (2020). APBN Kita Kinerja dan Fakta (2020). Didapatkan dari https://www.kemenkeu.go.id/media/14243/apbn-kita-januari-2020.pdf. Kementerian Keuangan. (1984). KMK-1002/KMK.04/1984 (1984). Didapatkan dari https://www.pajakku.com/tax-guide/127/KEP_MENKEU/1002/KMK.04/ 1984.

Kementerian Keuangan. (2018). PMK-35/PMK.010/2018 (2018). Didapatkan dari https://jdih.kemenkeu.go.id/fullText/2018/35 PMK.010 2018Per.pdf.

Kementerian Keuangan. (2015). PMK-169/PMK.010/2015 (2015). Didapatkan dari https://jdih.kemenkeu.go.id/fullText/2015/169 PMK.010 2015Per.pdf.

Khairunisa, K., Hapsari, D. W., \& Aminah, W. (2017). Kualitas Audit, Corporate Social Responsibility, dan Ukuran Perusahaan terhadap Tax Avoidance. Jurnal Riset Akuntansi Kontemporer (JRAK), 9(1), 39-46.

Nugroho, A., \& Suryarini, T. (2018). Determinant of Thin Capitalization in Multinational Companies in Indonesia. Journal of Accounting and Strategic Finance, 1(2), 91-100.

Organisation for Economic Cooperation and Development. (2012). Thin Capitalisation Legislation a Background Paper for Country Tax Administrations. Didapatkan dari http://www.oecd.org/ctp/tax-global/5.\%20thin_capitalization_background.pdf.

Organisation for Economic Cooperation and Development. (2020). Revenue Statistics in Asian and Pacific Economies 2020 - Indonesia. Didapatkan dari 
https://www.oecd.org/tax/tax-policy/revenue-statistics-asia-and-pacific-indonesia.pdf.

Presiden Republik Indonesia. (2015). PP 18 Tahun 2015 (2015). Didapatkan dari https://peraturan.bkpm.go.id/jdih/userfiles/batang/PP\%2018\%202015\% 20FASILITAS\%20PAJAK\%20PENGHASILAN\%20UNTUK\%20PENANAMAN\% 20MODAL\%20DI\%20BIDANG\%20USAHA\%20TTT\%20DAN\%20ATAU\% 20DAERAH\%20TTT.pdf.

Pratama, A. (2017). Does Corporate Governance Reduce Thin Capitalization Practice? The Case of Indonesian Manufacturing Firms. Review of Integrative Business and Economics Research, 6(4), 276-284.

Purba, A. \& Tran, A. (2018). Cross-border profit shifting: Evidence from Indonesia. Didapat dari https://www.business.unsw.edu.au/About-Site/ Schools-Site/Taxation-Business-Law-Site/Documents/42-Purba-Tran-ATTA 2018.pdf.

Purba, D. F. \& Kholis A. (2017). Pengaruh Ukuran Perusahaan, Struktur Kepemilikan, Profitabilitas, Leverage dan Umur Perusahaan terhadap Pengungkapan Informasi Intellectual Capital Pada Perusahaan Perbankan di Bursa Efek Indonesia. Jurnal Mediasi Unimed, 6(1), 1-15.

Putranti, T. W., Jati, W., \& Tambunan, M. (2015). Studi Penghindaran Pajak Kegiatan Jasa Perbankan di Indonesia. Didapat dari https://responsibank.id/ media/277207/case-study-responsibank-indonesia_studi-penghindaran-pajakkegiatan-jasa-perbankan-indonesia.pdf, 21 Agustus 2020, pukul 19:46 WIB. Suntari, M. \& Mulyani, S. D. (2020). Pengaruh Transfer Pricing dan Thin Capitalization Terhadap Tax Aggressiveness Dimoderasi oleh Ukuran Perusahaan. Prosiding Seminar Nasional Pakar 3(2), 271-278.

Utami, E. M. \& Hidayah, R. T. (2017). The Influence of Capital Structure on Earning Per Share (Eps). Jurnal Riset Manajemen Sains Indonesia (JRMSI), $8(2), 241-257$.

Waluyo, W. \& Doktrolalina, C. M. (2018). Factors Affecting Tax Avoidance through Thin Capitalisation: Multinational Enterprises in Indonesia. Int. J. Manag. Bus. Res., 8 (3), 210-216.

Yadiati, W. \& Mubarok, A. (2017). Kualitas Pelapor Keuangan: Kajian Teoretis dan Empiris (edisi ke-1). Jakarta: Penerbit Kencana. 
Journal of Accounting, Entrepreneurship, and Financial Technology

Volume 02, Number 02, April 2021

Yulyanah \& Kusumastuti, Y. S. (2019). Tax Avoidance pada Perusahaan Manufaktur Sektor Industri Barang dan Konsumsi Sub Sektor Makanan dan Minuman yang Terdaftar di Bursa Efek Indonesia. Media Ekonomi, 27(1), 17-36. 